\title{
Priprema i ispitivanje svojstava polimernih mješavina na osnovi PLA
}

\author{
F. Car, I. Ćevid, I. El-Sayed, Z. Hajdari Gretić i D. Vrsaljko \\ Sveučilište u Zagrebu, Fakultet kemijskog inženjerstva i tehnologije, \\ Marulićev trg 19, 10000 Zagreb
}

Ovo djelo je dano na korištenje pod Creative Commons Attribution 4.0 International License

\begin{abstract}
Sažetak
U ovom radu pripremljene su polimerne mješavine polilaktida (PLA), polietilena visoke gustoće (PE-HD) i polietilena niske gustoće (PE-LD) u različitim omjerima. Umješavanje polimera i njihovih mješavina izvršeno je pomoću ekstrudera i gnjetilice, nakon čega su im određena mehanička, toplinska i morfološka svojstva.

Rezultati mehaničkih ispitivanja pokazali su da dodatak polietilena (PE-LD i PE-HD) čistom polilaktidu znatno mijenja njegova mehanička svojstva. Analiza provedena na pretražnom elektronskom miskroskopu (SEM) i razlikovnom pretražnom kalorimetru (DSC) pokazala je da ispitani polimeri nisu mješljivi. Ispitivane polimerne mješavine djelomično su biorazgradljive, a postignuto je i smanjenje cijene materijala u usporedbi s čistim polilaktidom.
\end{abstract}

Ključne riječi

Polimerne mješavine, PLA, PE-HD, PE-LD, mehanička svojstva, toplinska svojstva, morfološka svojstva

\section{Uvod}

Polimeri se u praksi sve više upotrebljavaju kao tehnički materijali zbog vrlo povoljnih karakteristika kao što su laka preradba, relativno niska gustoća, niska električna provodljivost kao i dobra zvučna te korozijska zaštita. Godišnje se u svijetu proizvodi preko 300 milijuna tona polimera, a najviše se upotrebljavaju kod proizvodnje ambalaže, u graditeljstvu, medicini, kemijskoj industriji itd. Dakle, polimeri su upravo zbog svoje široke uporabe u današnjem društvu postali nezaobilazni materijali. Njihov daljnji razvoj nije više okrenut samo ka dobivanju što kvalitetnijeg proizvoda već i dobivanju proizvoda koji će imati minimalni štetni utjecaj na okoliš. ${ }^{1-3}$

Svojstva polimera mogu se definirati kao značajke koje se određuju standardnim metodama ispitivanja te se mogu podijeliti u dvije velike skupine, mehanička i nemehanička svojstva. Termin mehanička svojstva polimera odnosi se na ponašanje materijala pod utjecajem mehaničkog naprezanja. Najznačajnija mehanička svojstva su čvrstoća, žilavost i tvrdoća, dok su nemehanička svojstva npr. toplinske karakteristike te otpornost na djelovanje agresivnih medija (bubrenje). ${ }^{2}$

Polietilen spada $u$ žilave materijale koje odlikuje relativno visok modul elastičnosti. Uz samu morfologiju, na njegova svojstva znatan utjecaj ima veličina i raspodjela veličina molekulskih masa. Uska raspodjela molekulskih masa karakteristična je za polietilen visoke gustoće (PE-HD), dok je široka raspodjela molekulskih masa karakteristična kod polietilena niske gustoće (PE-LD). ${ }^{1}$

Polilaktid (PLA) je homopolimer mliječne kiseline poznat više od 80 godina. PLA je termoplastičan materijal $s$ relativno visokim modulom elastičnosti (višim od polietilena), vlačnom čvrstoćom i malom vrijednosti elongacije pri lomu. U usporedbi s ostalim termoplastičnim materijalima, PLA se pokazao relativno krhkim materijalom s malom udarnom čvrstoćom te osjetljivošću na utjecaj vlage, no treba naglasiti i iznimno dobra termomehanička svojstva i djelomičnu biorazgradljivost. $U$ današnjem svijetu u kojem je sve razvijenija ekološka svijest, posebice potreba za recikliranjem, održivim upravljanjem resursima i minimalizacijom onečišćujućih emisija u okoliš, PLA se može uzeti kao primjer polimernog materijala kakvom treba težiti. ${ }^{4,5}$

Polimerne mješavine sastoje se od više polimera koji miješanjem daju nove materijale boljih svojstava u odnosu na komponente početne mješavine. Takav način dobivanja novih materijala često se primjenjuje $u$ industriji jer je jeftiniji i vremenski kraći u odnosu na sintezu novih polimernih materijala. ${ }^{6}$

Svojstva polimernih mješavina kontrolirana su njihovom morfologijom te međudjelovanjima komponenata unutar

\footnotetext{
* Autor za dopisivanje: Ivana Ćevid

e-pošta: icevid@fkit.hr
} 
same mješavine. Potpuno nemješljivi polimeri rezultirat će heterogenom strukturom s relativno lošim svojstvima. Međusobno mješljivi polimeri daju homogene mješavine poboljšanih svojstava u usporedbi s ishodnim čistim polimerima. Kod djelomično mješljivih polimera uočena su bolja svojstva novo dobivenog materijala. ${ }^{6,7}$

Kao i kod svakog proizvodnog procesa, tako i kod procesa dobivanja polimernih mješavina potrebno je odrediti karakteristike materijala koji se žele dobiti. To najčešće uključuje definiranje željenih fizikalnih i kemijskih svojstava dobivene mješavine te selekciju komponenata koje mogu pridonijeti željenim svojstvima. Nakon određivanja željenih svojstava, treba odrediti mješljivost faza. U slučaju da se radi o nemješljivom ili djelomično mješljivom sustavu, potrebno je odrediti metode kompatibilizacije.

Glavni razlozi za razvoj novih polimernih mješavina su poboljšanje mehaničkih i nemehaničkih svojstava materijala, smanjenje cijene s obzirom na čiste polimere, razvoj materijala željenih svojstava, mogućnost recikliranja itd. ${ }^{7,8}$

U ovom radu ispitana su mehanička, toplinska i morfološka svojstva čistih polimera, kao i nekoliko njihovih mješavina pripremljenih u različitim omjerima te pri različitim uvjetima priprave. Testirane su tri hipoteze. Prva hipoteza je da će promjenom uvjeta miješanja doći do promjena u morfologiji samih mješavina. Druga hipoteza je da morfologija ima velik utjecaj na mehanička svojstva dobivenih polimernih mješavina, pa će se promjenom morfoloških svojstava mijenjati i mehanička svojstva samih mješavina. Na koncu će biti testirana i treća hipoteza prema kojoj veličine domena (faza) mogu utjecati na položaj staklišta $\left(T_{\mathrm{g}}\right)$ i mješljivost faza.

Cilj rada je dobivanje polimernih mješavina polilaktida i polietilena čime bi se potencijalno mogao eliminirati jedan od glavnih nedostataka polilaktida, a to je njegova krtost. Uz smanjenje krtosti očekuje se i smanjenje cijene materijala u usporedbi s čistim polilaktidom, čija je cijena na tržištu znatno veća od cijene polietilena. Osim modificiranja svojstava polilaktida, cilj je i optimiranje morfologije polimerne mješavine polilaktida i polietilena u omjeru 90/10 s ciljem dobivanja dispergirane faze dimenzije promjera čestica $10 \mu \mathrm{m}$ do $20 \mu \mathrm{m}$ međusobno udaljenih $50 \mu \mathrm{m}$ do $150 \mu \mathrm{m}$. Takva morfologija nakon jetkanja površine induktivno spregnutom plazmom stvara površinsku hrapavost od koje očekujemo znatno povećane hidrofobnosti. ${ }^{9}$

\section{Eksperimentalni dio}

\subsection{Materijali}

U radu su upotrijebljeni polietilen visoke gustoće, polietilen niske gustoće i polilaktid (tablica 1).
Tablica 1 - Ispitivani polimeri

Table 1 - Investigated polymers

\begin{tabular}{|c|c|c|}
\hline $\begin{array}{l}\text { Materijal } \\
\text { Material }\end{array}$ & $\begin{array}{c}\text { Kratica } \\
\text { Abbreviation }\end{array}$ & $\begin{array}{l}\text { Proizvođač } \\
\text { Manufacturer }\end{array}$ \\
\hline $\begin{array}{l}\text { polietilen visoke } \\
\text { gustoće } \\
\text { high density } \\
\text { polyethylene }\end{array}$ & PE-HD & $\begin{array}{l}\text { Dow Europe } \mathrm{GmbH} \text {, } \\
\text { Švicarska } \\
\text { Dow Europe } \mathrm{GmbH} \text {, } \\
\text { Switzerland }\end{array}$ \\
\hline $\begin{array}{l}\text { polietilen niske } \\
\text { gustoće } \\
\text { low density } \\
\text { polyethylene }\end{array}$ & PE-LD & $\begin{array}{l}\text { Dow Europe } \mathrm{GmbH} \text {, } \\
\text { Švicarska } \\
\text { Dow Europe GmbH, } \\
\text { Switzerland }\end{array}$ \\
\hline $\begin{array}{l}\text { polilaktid } \\
\text { polylactide }\end{array}$ & PLA & $\begin{array}{l}\text { Nature Works LLC, SAD } \\
\text { Nature Works LLC, USA }\end{array}$ \\
\hline
\end{tabular}

Za pripravu polimernih mješavina i njihovo homogeniziranje upotrijebljeni su ekstruder i gnjetilica. Sastavi pripremljenih mješavina prikazani su u tablici 2.

$200 \mathrm{~g}$ smjese PLA/PE-LD i PLA/PE-HD u masenim omjerima navedenim $u$ tablici 2 umješavano je $u$ ekstruderu.

Tablica 2 - Sastav pripremljenih mješavina u ekstruderu

Table 2 - Composition of blends in the extruder

\begin{tabular}{c|c}
\hline PLA $/$ mas. $\%$ & PE-LD/PE-HD $/$ mas. $\%$ \\
\hline 0 & 100 \\
10 & 90 \\
20 & 80 \\
50 & 50 \\
80 & 20 \\
90 & 10 \\
95 & 5 \\
\hline
\end{tabular}

40 g smjese PLA/PE-LD i PLA/PE-HD u masenim omjerima 90/10 umješavano je u gnjetilici.

\subsection{Priprava uzoraka}

Polimerne mješavine različitih udjela polilaktida te polietilena visoke odnosno niske gustoće pripremljene su i ispitivane na sljedeći način:

1. miješanje:

a. smjesa polilaktida i polietilena (PE-HD ili PE-LD) od $200 \mathrm{~g}$ umiješana je u Rondol dvopužnom zonskom ekstruderu pri temperaturi od $160{ }^{\circ} \mathrm{C}$ te 50 o min ${ }^{-1}$

b. smjesa polilaktida i polietilena (PE-HD ili PE-LD) od $40 \mathrm{~g}$ umiješana je u Brabender gnjetilicu pri temperaturi od $170{ }^{\circ} \mathrm{C}$ te 45 odnosno $60 \mathrm{o} \mathrm{min}^{-1} \mathrm{u}$ vremenu od $10 \mathrm{~min}$

2. usitnjavanje:

a. dobiveni ekstrudat se hladi zatim sjecka na manje dijelove u sjeckalici 
b. kod gnjetilice se dobije masa koja se zatim ručno izrezuje na manje dijelove

3. usitnjena smjesa zatim se stavi u kalup te ide na prešanje pri $190^{\circ} \mathrm{C}$

4. iz dobivene isprešane mase izrezuju se epruvete (ravne i oblika vesla; epruvete ravnog oblika upotrijebljene su za mješavine koje su sadržavala 50 mas. \% i više polilaktida, dok su se epruvete oblika vesla upotrijebile za polimerne mješavine s manje od 50 mas. \% PLA)

5. epruvete se podvrgavaju rasteznom ispitivanju na univerzalnoj mehaničkoj kidalici Zwick 1445 (ravne epruvete - brzina istezanja $10 \mathrm{~mm} \mathrm{~min}^{-1}$, razmak čeljusti $50 \mathrm{~mm}$; epruvete oblika vesla - brzina istezanja $50 \mathrm{~mm} \mathrm{~min}^{-1}$, razmak čeljusti $30 \mathrm{~mm}$ )

6. toplinska svojstva uzoraka se zatim ispituju na diferencijalnom pretražnom kalorimetru (DSC) Mettler Toledo DSC832 ; mase uzoraka su približno $10 \mathrm{mg}$, provedena su DSC ispitivanja u dva ciklusa zagrijavanja i hlađenja u intervalu od $20{ }^{\circ} \mathrm{C}$ do $200{ }^{\circ} \mathrm{C}$, te uz brzinu zagrijavanja od $10{ }^{\circ} \mathrm{C} \mathrm{min}^{-1}$

7. uvid u strukturu nekih uzoraka određen je pomoću pretražnog elektronskog mikroskopa (SEM) Vega Tescan; prije ispitivanja uzorci su napareni zlatom radi povećanja električne vodljivosti.

Tablica 3 - Rezultati ispitivanja mehaničkih svojstava polimernih mješavina na osnovi PLA i PE-HD pripremljenih u ekstruderu Table 3 - Results of mechanical properties tests of polymer blends based on PLA and PE-HD prepared in the extruder

\begin{tabular}{l|c|c|c|c|c|c|c|c}
\hline \multicolumn{7}{c}{ PLA/PE-HD } \\
\hline $\begin{array}{l}\text { Uzorak } \\
\text { Specimen }\end{array}$ & $\sigma_{\mathrm{Y} / \mathrm{N} \mathrm{m}^{-2}}$ & $\varepsilon_{\mathrm{Y}} / \%$ & $\mathrm{~N} \mathrm{~mm}{ }^{-2}$ & $\varepsilon_{\mathrm{M}} / \%$ & $\sigma_{\mathrm{B}} / \mathrm{N} \mathrm{mm}^{-2}$ & $\varepsilon_{\mathrm{B}} / \%$ & $E / \mathrm{Nmm}^{-2}$ & $W / \mathrm{N} \mathrm{m}^{\circ}$ \\
\hline PLA & $/$ & $/$ & $48,9 \pm 2,9$ & $4,5 \pm 0,5$ & $48,9 \pm 2,9$ & $4,5 \pm 0,5$ & $1338 \pm 90$ & $0,77 \pm 0,11$ \\
PLA/PE-HD 95/5 & $/$ & $/$ & $44,4 \pm 3,7$ & $4,1 \pm 0,4$ & $44,4 \pm 3,7$ & $4,1 \pm 0,4$ & $1351 \pm 66$ & $0,62 \pm 0,11$ \\
PLA/PE-HD 90/10 & $/$ & $/$ & $39,8 \pm 1,2$ & $3,7 \pm 0,2$ & $39,8 \pm 1,2$ & $3,7 \pm 0,2$ & $1323 \pm 103$ & $0,33 \pm 0,09$ \\
PLA/PE-HD 80/20 & $/$ & $/$ & $25,2 \pm 1,7$ & $2,4 \pm 0,1$ & $10,5 \pm 0,1$ & $2,8 \pm 0,1$ & $1207 \pm 116$ & $0,19 \pm 0,01$ \\
PLA/PE-HD 50/50 & $12,4 \pm 0,6$ & $1,6 \pm 0,2$ & $12,8 \pm 0,9$ & $2,0 \pm 0,3$ & $10,1 \pm 0,9$ & $3,3 \pm 0,4$ & $596 \pm 143$ & $0,11 \pm 0,02$ \\
PLA/PE-HD 20/80 & $19,6 \pm 0,6$ & $3,4 \pm 0,6$ & $19,7 \pm 0,5$ & $4,1 \pm 0,9$ & $6,2 \pm 0,7$ & $77,8 \pm 19,1$ & $765 \pm 82$ & $2,39 \pm 0,42$ \\
PLA/PE-HD 10/90 & $22,1 \pm 0,5$ & $5,5 \pm 0,1$ & $22,4 \pm 0,5$ & $6,8 \pm 0,2$ & $8,7 \pm 0,3$ & $512,7 \pm 110,4$ & $663 \pm 31$ & $17,37 \pm 4,21$ \\
PE-HD & $25,0 \pm 0,3$ & $8,2 \pm 0,5$ & $25,2 \pm 0,2$ & $9,6 \pm 0,4$ & $10,0 \pm 0,3$ & $778,9 \pm 115,3$ & $639 \pm 38$ & $29,12 \pm 5,23$ \\
\hline
\end{tabular}

\section{Rezultati i rasprava}

\subsection{Rezultati ispitivanja mehaničkih svojstva}

Rezultati ispitivanja mehaničkih svojstava prikazuju srednje vrijednosti rasteznih ispitivanja provedenih na pet epruveta za svaki uzorak. Ispitanim uzorcima određeni su: naprezanje kod popuštanja $\left(\sigma_{\mathrm{Y}}\right)$, istezanje kod popuštanja $\left(\varepsilon_{Y}\right)$, vlačna čvrstoća $\left(\sigma_{M}\right)$, istezanje kod vlačne čvrstoće $\left(\varepsilon_{M}\right)$, naprezanje kod loma $\left(\sigma_{\mathrm{B}}\right)$, istezanje kod loma $\left(\varepsilon_{\mathrm{B}}\right)$, Youngov modul (E) i rad loma (W). Rezultati mjerenja (tablica 3) potvrdili su da je vlačna čvrstoća čistog PLA $\left(\sigma_{\mathrm{M}}=48,9 \pm 0,5 \mathrm{~N} \mathrm{~mm}^{-2}\right)$ gotovo dvostruko veća od vlačne čvrstoće čistog PE-HD-a $\left(\sigma_{\mathrm{M}}=25,2 \pm 0,2 \mathrm{~N} \mathrm{~mm}^{-2}\right)$ te da je vrijednost istezanja kod loma PE-HD-a $\left(\varepsilon_{\mathrm{B}}=778,9 \pm 115,3 \%\right)$ znatno veća od istezanja kod loma $\operatorname{PLA}\left(\varepsilon_{B}=4,5 \pm 0,5 \%\right.$ ), što se moglo očekivati jer je PE-HD žilav materijal, dok se PLA ubraja u krte materijale. Može se primijetiti trend smanjenja vrijednosti mehaničkih svojstava dodatkom PE-HD-a u PLA, te su vrijednosti vlačne čvrstoće naprezanja kod loma i Youngovog modula niže u odnosu na čisti PLA.

Na osnovi mehaničkih svojstava (tablica 4) vidljivo je da je vlačna čvrstoća čistog PLA $\left(\sigma_{\mathrm{M}}=48,9 \pm 2,9 \mathrm{~N} \mathrm{~mm}^{-2}\right)$ približno četiri puta veća od vlačne čvrstoće čistog PE-LDa $\left(\sigma_{\mathrm{M}}=11,8 \pm 0,9 \mathrm{~N} \mathrm{~mm}^{-2}\right)$ te da je vrijednost prekidnog istezanja PE-LD-a $\left(\varepsilon_{\mathrm{B}}=443,8 \pm 75,5 \%\right)$ znatno veća od prekidnog istezanja PLA ( $\left.\varepsilon_{\mathrm{B}}=4,5 \pm 0,5 \%\right)$. Usporedbom vrijednosti mehaničkih svojstava iz tablica 3 i 4 možemo uočiti da je vrijednost istezanja kod loma PE-HD $\left(\varepsilon_{\mathrm{B}}=778,9 \pm 115,3 \%\right)$ približno dva puta veća od prekidnog istezanja PE-LD ( $\left.\varepsilon_{B}=443,8 \pm 75,5 \%\right)$. Može se primijetiti isti trend smanjenja vrijednosti mehaničkih svojstava dodatkom PE-LD-a u PLA, kao i dodatkom PEHD-a u PLA. Iz tablice 4 vidljivo je znatnije smanjenje vrijednosti Youngovog modula s povećanjem udjela PELD-a, što bi značilo da se smanjila krutost PLA. 
Tablica 4 - Rezultati ispitivanja mehaničkih svojstava polimernih mješavina na osnovi PLA i PE-LD pripremljenih u ekstruderu Table 4 - Results of mechanical properties tests of polymer blends based on PLA and PE-LD prepared in the extruder

\begin{tabular}{l|c|c|c|c|c|c|c|c}
\hline \multicolumn{7}{c}{ PLA/PE-LD } \\
\hline $\begin{array}{l}\text { Uzorak } \\
\text { Specimen }\end{array}$ & $\sigma_{\mathrm{Y} / \mathrm{N} \mathrm{mm}}^{-2}$ & $\varepsilon_{\mathrm{Y}} / \%$ & $\mathrm{~N} \mathrm{~mm}^{-2}$ & $\varepsilon_{\mathrm{M}} / \%$ & $\sigma_{\mathrm{B}} / \mathrm{N} \mathrm{mm}^{-2}$ & $\varepsilon_{\mathrm{B}} / \%$ & $E / \mathrm{Nm}^{-2}$ & $W / \mathrm{N} \mathrm{m}$ \\
\hline PLA & $/$ & $/$ & $48,9 \pm 2,9$ & $4,5 \pm 0,5$ & $48,9 \pm 2,9$ & $4,5 \pm 0,5$ & $1338 \pm 90$ & $0,77 \pm 0,11$ \\
PLA/PE-LD 95/5 & $/$ & $/$ & $40,0 \pm 3,1$ & $4,1 \pm 0,2$ & $37,6 \pm 2,8$ & $6,6 \pm 1,0$ & $1321 \pm 89$ & $0,99 \pm 0,22$ \\
PLA/PE-LD 90/10 & $/$ & $/$ & $30,0 \pm 1,5$ & $3,6 \pm 0,2$ & $29,7 \pm 2,9$ & $4,5 \pm 0,5$ & $1205 \pm 65$ & $0,49 \pm 0,08$ \\
PLA/PE-LD 80/20 & $/$ & $/$ & $21,2 \pm 1,3$ & $3,7 \pm 0,3$ & $21,2 \pm 1,3$ & $3,7 \pm 0,3$ & $984 \pm 95$ & $0,30 \pm 0,09$ \\
PLA/PE-LD 50/50 & $/$ & $/$ & $12,0 \pm 0,9$ & $2,8 \pm 0,3$ & $9,5 \pm 4,5$ & $3,7 \pm 0,5$ & $553 \pm 32$ & $0,13 \pm 0,03$ \\
PLA/PE-LD 20/80 & $10,2 \pm 1,3$ & $4,1 \pm 0,8$ & $10,4 \pm 1,3$ & $4,7 \pm 0,7$ & $1,2 \pm 2,1$ & $20,9 \pm 3,1$ & $324 \pm 29$ & $0,27 \pm 0,08$ \\
PLA/PE-LD 10/90 & $8,6 \pm 0,4$ & $8,9 \pm 0,2$ & $8,7 \pm 0,4$ & $9,6 \pm 1,8$ & $4,2 \pm 1,5$ & $26,3 \pm 7,3$ & $172 \pm 11$ & $0,47 \pm 0,17$ \\
PE-LD & $8,3 \pm 0,2$ & $16,6 \pm 0,9$ & $11,8 \pm 0,9$ & $443,8 \pm 75,5$ & $11,2 \pm 2,8$ & $453,3 \pm 91,4$ & $119 \pm 1$ & $11,41 \pm 2,97$ \\
\hline
\end{tabular}

Tablica 5 - Rezultati ispitivanja mehaničkih svojstava polimernih mješavina na osnovi PLA i PE-HD, te PLA i PE-LD pripremljenih u gnjetilici

Table 5 - Results of mechanical properties tests of polymer blends based on PLA and PE-HD and PLA and LD-PE prepared in the kneader

\begin{tabular}{c|c|c|c|r|r|r}
\hline \multicolumn{7}{c}{ PLA/PE-HD 90/10 } \\
\hline $\begin{array}{c}\text { Brzina okretaja, o min } \\
\text { Rotation per minute, } \mathrm{rpm}\end{array}$ & $\sigma_{\mathrm{Y}} / \mathrm{N} \mathrm{mm}^{-2}$ & $\varepsilon_{\mathrm{Y}} / \%$ & $\sigma_{\mathrm{B}} / \mathrm{N} \mathrm{mm}^{-2}$ & $\varepsilon_{\mathrm{B}} / \%$ & $E / \mathrm{N} \mathrm{mm}^{-2}$ & $W / \mathrm{N} \mathrm{m}$ \\
\hline 45 & $36,3 \pm 3,7$ & $3,7 \pm 0,4$ & $36,3 \pm 3,7$ & $3,7 \pm 0,4$ & $1264 \pm 92$ & $0,46 \pm 0,12$ \\
60 & $41,8 \pm 3,1$ & $4,1 \pm 0,3$ & $41,8 \pm 3,1$ & $4,1 \pm 0,3$ & $1258 \pm 54$ & $0,53 \pm 0,07$ \\
\hline & \multicolumn{7}{c}{ PLA/PE-LD 90/10 } \\
65 & $41,6 \pm 1,8$ & $4,5 \pm 0,2$ & $38,7 \pm 6,8$ & $6,6 \pm 0,5$ & $1313 \pm 38$ & $1,01 \pm 0,13$ \\
60 & $42,1 \pm 3,1$ & $4,1 \pm 0,3$ & $40,4 \pm 2,5$ & $6,2 \pm 1,2$ & $1380 \pm 73$ & $0,95 \pm 0,21$ \\
\hline
\end{tabular}

Tablica 5 prikazuje rezultate ispitivanja mehaničkih svojstava za polimerne mješavine PLA/PE-HD i PLA/PE-LD pripremljene $u$ gnjetilici. Uočava se trend porasta vrijednosti vlačne i prekidne čvrstoće s povećanjem broja okretaja za obje polimerne mješavine. Iz toga se može pretpostaviti da povećanjem broja okretaja dolazi do stvaranja specifične morfologije polimernih mješavina, što u tom slučaju dovodi do boljih mehaničkih svojstava.

\subsection{Rezultati ispitivanja toplinskih svojstva}

Primjenom DSC analize određena su toplinska svojstva čistih polimera i pripremljenih polimernih mješavina. Rezultati ispitivanja toplinskih svojstava dobiveni iz DSC termograma prikazani su u tablici 6. Iz krivulja zagrijavanja određene su temperature staklastog prijelaza, $T_{\mathrm{g}}$, hladne kristalizacije, $T_{\mathrm{cc}}$ i taljenja, $T_{m}$, te odgovarajuće entalpije kristalizacije i taljenja, $\Delta H_{\mathrm{cc}}$ i $\Delta H_{\mathrm{m}}$. Ispitana su samo toplinska svojstva polimernih mješavina iz tablice 6 zbog znatnog smanjenja vrijednosti vlačne čvrstoće i naprezanja kod loma mješavina u kojima je maseni udio PLA manji od 90 \%.

Prema literaturi, temperatura taljenja, $T_{m}$, PLA se nalazi $u$ rasponu između $144,9{ }^{\circ} \mathrm{C}$ i $185,9{ }^{\circ} \mathrm{C}$, PE-HD-a između $117,9{ }^{\circ} \mathrm{C}$ i $145,9{ }^{\circ} \mathrm{C}$, te PE-LD-a između $104,9{ }^{\circ} \mathrm{C}$ i $114,9^{\circ} \mathrm{C} .{ }^{10-12}$ Može se uočiti da vrijednosti (tablica 6) temperatura taljenja, $T_{\mathrm{m}}$ za tri čista polimera ulaze $\mathrm{u}$ teorijski raspon, prema literaturi. ${ }^{10-12}$ Promatrajući vrijednosti $T_{\mathrm{m}}$ za polimerne mješavine, vidljivo je da ne dolazi do značajnih promjena u vrijednostima temperatura taljenja pri dodatku 5 mas. \% ili 10 mas. \% PE-HD-a. Kod mješavina s PE-LD-om uočavaju se nešto veće razlike nego kod mješavina s PE-HD-om, međutim i dalje se ne može govoriti o značajnijim promjenama. Vrijednosti $T_{\mathrm{mPE}}$ i $\Delta H_{\mathrm{mPE}}$ za polimernu mješavinu PLA/PE-LD 95/5 umješavanu na ekstruderu nije moguće očitati iz DSC termograma jer je došlo do preklapanja područja hladne kristalizacije i taljenja polietilena (označeno u tablici 6 sa simbolom *). Prema literaturi, temperatura staklastog prijelaza polilaktida nalazi se između $49,9{ }^{\circ} \mathrm{C}$ i $56,9^{\circ} \mathrm{C}$, PE-HD-a između $-133,15^{\circ} \mathrm{C}$ do $-113,15^{\circ} \mathrm{C}$ te PE-LD-a između $-133,2{ }^{\circ} \mathrm{C}$ do $-103,2{ }^{\circ} \mathrm{C} .{ }^{10-12}$ Rezultati toplinskih ispitivanja pokazuju da je dobivena vrijednost $T_{\mathrm{g}}$ PLA unutar raspona teorijske vrijednosti, a za polietilene na DSC termogramima nije određena vrijednost $T_{\mathrm{g}}$ jer su se DSC ispitivanja provodila u rasponu temperatura od $20{ }^{\circ} \mathrm{C}$ do $200{ }^{\circ} \mathrm{C}$. Iz tablice 6 vidljivo je da su vrijednosti staklišta polimernih mješavina gotovo nepromijenjene dodatkom 5 mas. \% ili 10 mas. \% oba polietilena, s obzirom na vrijednost čistog PLA, te se iz toga može zaključiti da ispitani polimeri nisu mješljivi jer se ne približavaju literaturnim vrijednostima $T_{\mathrm{g}}$ polietilena. Primijećen je i 
značajan pad vrijednosti entalpija taljenja i kristalizacije, što se može povezati sa samom kristalnom strukturom ispitivanih polimera. Polilaktid je kristalasti polimer, dok je polietilen amorfan polimer. Stoga je povećanjem masenog udjela amorfnog polimera u polimernoj mješavini došlo do pada vrijednosti navedenih entalpija.

\subsection{Rezultati ispitivanja morfoloških svojstva}

Na slici 1 prikazane su mikrofotografije površina loma nakon mehaničkog ispitivanja čistih polimera. Kod mikrofotografije površine loma polilaktida vidljivo je da se radi o krtom materijalu i jednofaznom sustavu, dok su na obje snimke uzoraka polietilena vidljivi fibrili koji su karakteristični za žilave materijale. Ispitana su morfološka svojstva istih polimernih mješavina kao i kod ispitivanja toplinskih svojstava iz istih razloga.

Iz mikrofotografija mješavina PLA/PE-HD i PLA/PE-LD omjera 95/5 (slika 2) vidljivo je da se radi o dvofaznom sustavu, pri čemu su čestice polietilena dispergirane $u$ matrici polilaktida.

Tablica 6 - Toplinska svojstva čistih polimera i njihovih mješavina

Table 6 - Thermal properties of neat polymers and their blends

\begin{tabular}{|c|c|c|c|c|c|c|c|}
\hline $\begin{array}{l}\text { Uzorak } \\
\text { Specimen }\end{array}$ & $\sigma_{\mathrm{Y}} / \mathrm{N} \mathrm{mm}^{-2}$ & $\varepsilon_{Y} / \%$ & $\mathrm{~N} \mathrm{~mm}^{-2}$ & $\varepsilon_{M} / \%$ & $\sigma_{\mathrm{B}} / \mathrm{N} \mathrm{mm}^{-2}$ & $\varepsilon_{\mathrm{B}} / \%$ & $E / \mathrm{N} \mathrm{mm}^{-2}$ \\
\hline PLA & 55,9 & 114,9 & 16,1 & 147,8 & 26,6 & - & - \\
\hline PE-HD & - & - & - & - & - & 136,8 & 199,8 \\
\hline PE-LD & - & - & - & - & - & 112,2 & 63,2 \\
\hline $\begin{array}{l}\text { PLA/PE-HD 90/10, ekstruder } \\
\text { extruder }\end{array}$ & 56,7 & 115,8 & 12,1 & 148,6 & 22,0 & 130,4 & 9,2 \\
\hline $\begin{array}{l}\text { PLA/PE-HD 90/10, gnjetilica } 45 \text { o } \text { min }^{-1} \\
\text { kneader } 45 \mathrm{rpm}\end{array}$ & 56,3 & 114,4 & 11,5 & 148,3 & 19,5 & 129,5 & 10,2 \\
\hline $\begin{array}{l}\text { PLA/PE-HD 90/10, gnjetilica } 60 \text { o } \text { min }^{-1} \\
\text { kneader } 60 \mathrm{rpm}\end{array}$ & 56,3 & 114,3 & 12,3 & 148,7 & 20,8 & 129,0 & 9,8 \\
\hline $\begin{array}{l}\text { PLA/PE-LD 90/10, ekstruder } \\
\text { extruder }\end{array}$ & 56,0 & 124,8 & 12,0 & 150,3 & 8,1 & 110,3 & 1,5 \\
\hline $\begin{array}{l}\text { PLA/PE-LD 90/10, gnjetilica } 45 \text { o } \text { min }^{-1} \\
\text { kneader } 45 \text { rpm }\end{array}$ & 59,6 & 127,6 & 4,0 & 151,0 & 3,3 & 108,6 & 0,5 \\
\hline $\begin{array}{l}\text { PLA/PE-LD 90/10, gnjetilica } 60 \text { o } \mathrm{min}^{-1} \\
\text { kneader } 60 \mathrm{rpm}\end{array}$ & 58,8 & 125,8 & 4,0 & 151,0 & 1,5 & 109,6 & 1,0 \\
\hline $\begin{array}{l}\text { PLA/PE-HD 95/5, ekstruder } \\
\text { extruder }\end{array}$ & 56,8 & 116,3 & 12,7 & 148,5 & 25,8 & 129,8 & 4,1 \\
\hline $\begin{array}{l}\text { PLA/PE-LD 95/5, ekstruder } \\
\text { extruder }\end{array}$ & 55,5 & 124,8 & 11,3 & 149,8 & 7,0 & $--^{*}$ & $-^{*}$ \\
\hline
\end{tabular}

*Vrijednosti nije moguće očitati iz termograma zbog toga što je došlo do preklapanja područja hladne kristalizacije i taljenja polietilena.

* The values cannot be read from the thermogram due to the overlap of the cold crystallization area and melting area of polyethylene.
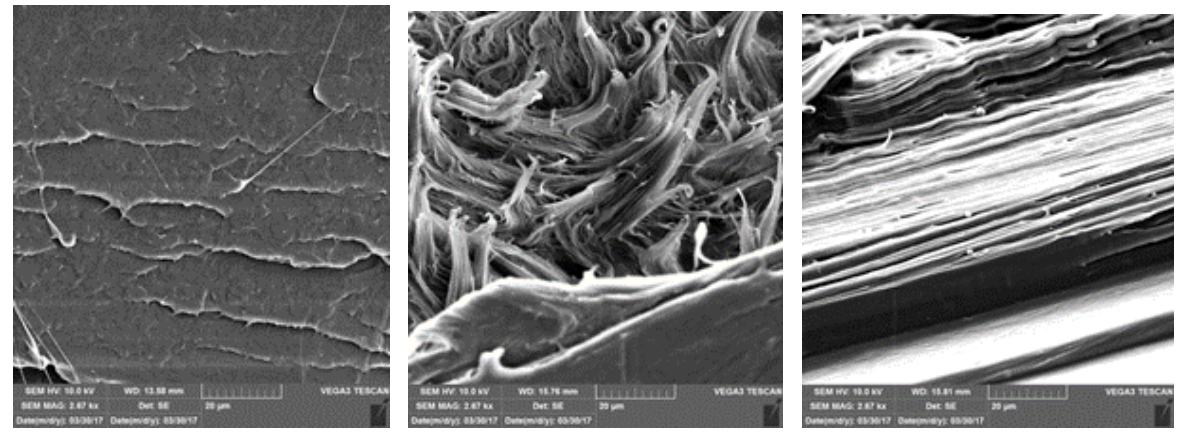

Slika 1 - Mikrofotografije površina loma čistih polimera (PLA - lijevo, PE-HD - sredina, PE-LD - desno)

Fig. 1 - Micrographs of fracture surface of neat polymers (PLA - left, PE-HD - middle, PE-LD - right) 

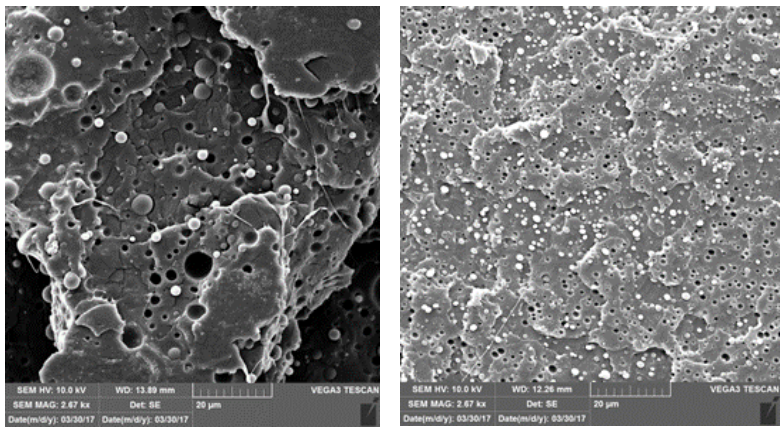

Slika 2 - SEM mikrofotografije površine loma mješavina PLA/PE-HD 95/5 (lijevo), te PLA/PE-LD 95/5 (desno), ekstruder

Fig. 2 - SEM micrographs of fracture surface of mixtures of PLA/PE-HD 95/5 (left), PLA/PE-LD 95/5 (right), extruder
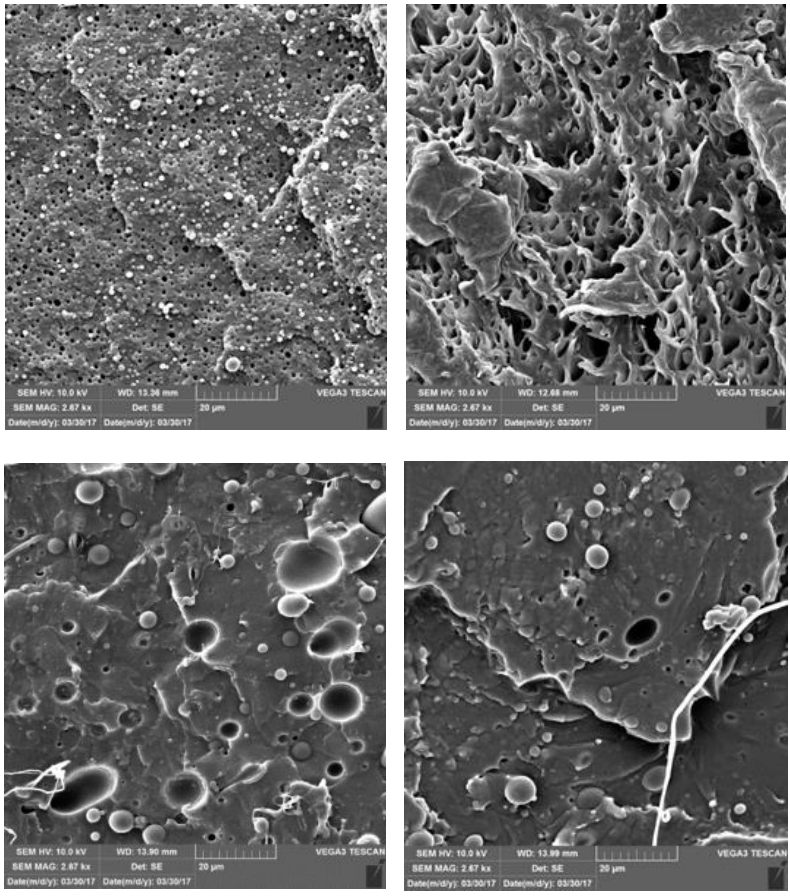

Slika 3 - Mikrografije mješavina PLA/PE-HD 90/10 dobivenih na gnjetilici pri 45 o min $^{-1}$ i

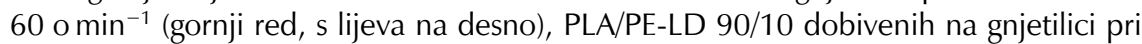
$45 \mathrm{o} \mathrm{min}^{-1}$ i 60 o $\mathrm{min}^{-1}$ (donji red, s lijeva na desno)

Fig. 3 - Micrographs of PLA/PE-HD blends 90/10 obtained in a kneader at $45 \mathrm{rpm}$ and $60 \mathrm{rpm}$ (upper row, from left to right), PLA/PE-LD blends 90/10 obtained in a kneader at 45 rpm and $60 \mathrm{rpm}$ (lower row, from left to right)

Kod mješavine PLA/PE-HD 95/5 veličine čestica se u prosjeku kreću od $1 \mu \mathrm{m}$ do $3 \mu \mathrm{m}$, dok su kod mješavine PLA/PE-LD istog omjera čestice većih dimenzija, a i sama raspodjela veličina čestica je šira, od $2 \mu \mathrm{m}$ do $10 \mu \mathrm{m}$.

Mikrofotografije površine loma uzoraka mješavina dobivenih na gnjetilici (slika 3) pokazuju slične rezultate. Jasno se vidi razlika u veličinama čestica i njihovoj raspodjeli ovisno o tipu $\mathrm{PE}$, pri čemu su čestice PE-LD-a veće nego čestice PE-HD-a, što je u tim sustavima rezultiralo boljim mehaničkim svojstvima (najveća čvrstoća i istezanje kod loma). Primjećuje se slična morfologija mješavina PLA/PE-LD 90/10 pripremljenih na gnjetilici i mješavina PLA/PE-LD 95/5 pripremljenih na ekstruderu. Također je vidljiva gotovo ista morfologija mješavina PLA/PE-HD 95/5 pripremljene na ekstruderu i PLA/PE-HD 90/10 pripremljene na gnjetilici pri $45 \mathrm{o} \mathrm{min}^{-1}$. 


\section{Zaključak}

U ovom radu ispitana su mehanička, toplinska i morfološka svojstva polimernih mješavina polilaktida i polietilena visoke i niske gustoće. Rezultati ispitivanja pokazali su da dodatak oba polietilena čistom polilaktidu značajno mijenja mehanička svojstva materijala, posebice vlačnu čvrstoću i Youngov modul. Čestice polietilena visoke gustoće imaju manje dimenzije, užu raspodjelu veličina čestica i pravilniji oblik od čestica polietilena niske gustoće kod istih udjela u mješavini. Analiza provedena na pretražnom elektronskom mikroskopu i diferencijalnom pretražnom kalorimetru pokazala je da ispitani polimeri nisu mješljivi.

Potvrđene su hipoteze da se promjenom uvjeta miješanja mijenja i morfologija mješavina, zbog čega se mijenjaju i njihova mehanička svojstva. Hipoteza da veličine domena (faza) mogu utjecati na položaj temperature staklastog prijelaza i mješljivost faza nije potvrđena, jer ispitani polimeri nisu mješljivi.

Valja naglasiti da su dobivene mješavine djelomično biorazgradljive, a dodatkom polietilena postignuto je i smanjenje cijene materijala s obzirom na čisti polilaktid, jer je tržišna cijena polietilena niža od cijene polilaktida.

\section{ZAHVALA}

Ovaj je rad financirala Hrvatska zaklada za znanost projektom UIP-2014-09-3154.

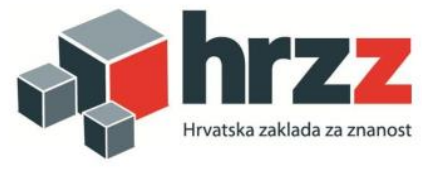

\section{Popis kratica i simbola}

\section{List of abbreviations and symbols}

\begin{tabular}{|c|c|}
\hline DSC & $\begin{array}{l}\text { - razlikovni pretražni kalorimetar } \\
\text { - Differential Scanning Calorimeter }\end{array}$ \\
\hline PE-HD & $\begin{array}{l}\text { - polietilen visoke gustoće } \\
\text { - high density polyethylene }\end{array}$ \\
\hline PE-LD & $\begin{array}{l}\text { - polietilen niske gustoće } \\
\text { - low density polyethylene }\end{array}$ \\
\hline PLA & $\begin{array}{l}\text { - polilaktid } \\
\text { - polylactide }\end{array}$ \\
\hline SEM & $\begin{array}{l}\text { - pretražna elektronska miskroskopija } \\
\text { - Scanning Electron Microscopy }\end{array}$ \\
\hline$\Delta H_{\mathrm{cc}}$ & $\begin{array}{l}\text { - entalpija kristalizacije, } \mathrm{Jg}^{-1} \\
\text { - crystallization enthalpy, } \mathrm{Jg}^{-1}\end{array}$ \\
\hline$H_{\mathrm{m}}$ & - entalpija taljenja, $\mathrm{Jg}^{-1}$ \\
\hline
\end{tabular}

- melting enthalpy, $\mathrm{Jg}^{-1}$

- naprezanje kod loma, $\mathrm{N} \mathrm{mm}^{-2}$

- strength at break, $\mathrm{N} \mathrm{mm}^{-2}$

- vlačna čvrstoća, $\mathrm{N} \mathrm{mm}^{-2}$

- tensile strength, $\mathrm{N} \mathrm{mm}^{-2}$

- naprezanje kod popuštanja, $\mathrm{N} \mathrm{mm}^{-2}$

- yield strength, $\mathrm{N} \mathrm{mm}^{-2}$

- prekidno istezanje, \%

- elongation at break, \%

- istezanje kod vlačne čvrstoće, \%

- elongation at tensile strength, \%

- istezanje kod popuštanja, \%

- elongation at yield, \%

- Youngov modul, $\mathrm{N} \mathrm{mm}^{-2}$

- Young's modulus, $\mathrm{N} \mathrm{mm}^{-2}$

- temperatura hladne kristalizacije, ${ }^{\circ} \mathrm{C}$

- cold crystallization temperature, ${ }^{\circ} \mathrm{C}$

- temperatura staklastog prijelaza, ${ }^{\circ} \mathrm{C}$

- glass transition temperature, ${ }^{\circ} \mathrm{C}$

- temperatura taljenja, ${ }^{\circ} \mathrm{C}$

- melting temperature, ${ }^{\circ} \mathrm{C}$

- rad loma, $\mathrm{N}$ m

- work to break, $\mathrm{N} \mathrm{m}$

\section{Literatura \\ References}

1. Z. Janović, Polimerizacije i polimeri, I. Butula (ur.), Hrvatsko društvo kemijskih inženjera i tehnologa, Zagreb, 1997, str. 10, 317-323.

2. Ž. Šimunić, Polimeri u graditeljstvu, Sveučilište u Zagrebu, Građevinski fakultet, Zagreb, 2006, str. 11, 65, 122.

3. URL:

https://www.statista.com/statistics/282732/global-

production-of-plastics-since-1950/ (pristup 15. 4. 2017.)

4. D. W. Farrington, J. Lunt, S. Davies, R.S. Blackburn, Polyesters and Polyamides, B. L. Deopura, R. Alagirusamy, M. Joshi, B. Gupta (ur.), Poly(lactic acid) fibers (PLA), Woodhead Publishing Series in Textiles, Cambridge England, 2008, str. 140-170.

5. URL:

http://sustpkgg.blogspot.hr/2009/07/pla-polylactide.html (pristup 5.5.2017.)

6. E. Govorčin Bajsić, Skripta Polimerne mješavine, Fakultet kemijskog inženjerstva i tehnologije, Zagreb, 2012.

7. D.R. Paul, Polymer blends, D. R. Paul, S. Newman (ur.), Fibers from Polymer Blends, Vol. 2, Academic Press, New York, 1978, str. 167-217.

8. L. Yu, K. Dean, L. Li, Polymer blends and composites from renewable resources, Prog. Poly. Sci. 31 (2006) 576-602, doi: https://doi.org/10.1016/j.progpolymsci.2006.03.002. 
9. D. Vrsaljko, I. Grčić, C. Guyon, G. Schelcher, M. Tatoulian, Designing Hydrophobicity of the PLA Polymer Blend Surfaces by ICP Etching, Plasma Process. Polym. 13 (2016), 869-878, doi: https://doi.org/10.1002/ppap.201500218.

10. L. Lu, A. G. Mikos, Polymer Data Handbook, J. E. Mark (ur.), Poly(lactic acid), Oxford University Press, New York, 1999. , str. 627-632.
11. L. Mandelkern, R. G. Alamo, Polymer Data Handbook, J. E. Mark (ur.), Polyethylene, linear high-density, Oxford University Press, New York, 1999., str. 493-505.

12. A. Prasad, Polymer Data Handbook, J. E. Mark (ur.), Polyethylene, low-density, Oxford University Press, New York, 1999., str. 518-528.

\section{SUMMARY}

\section{Preparation and Study of Polymer Blends Based on PLA}

Filip Car, Ivana Ćevid," Iman El-Sayed, Zana Hajdari Gretić, and Domagoj Vrsaljko

In this study, polymeric blends of polylactide (PLA), high density polyethylene (PE-HD) and low density polyethylene (PE-LD) in different ratios were prepared. Blending of polymers with an extruder and a kneader was performed. Mechanical, thermal, and morphological properties of the prepared blends were determined.

The results of mechanical testing showed that the addition of polyethylene (PE-LD and PE-HD) to pure polylactide significantly changed the mechanical properties of the material. The analysis performed on the scanning electron microscope (SEM) and the differential scanning calorimeter (DSC) showed that the investigated polymers were immiscible. The investigated polymer blends were partially biodegradable, while material price decreased compared to pure polylactide.

\section{Keywords}

Polymer blends, PLA, PE-HD, PE-LD, mechanical properties, thermal properties, morphological properties 